\title{
Karakteristik Fisik dan Fungsional Pati Keladi (Xanthosoma sagittifolium) dari Beberapa Lokasi di Maluku
}

\section{Physical and Functional Characteristic of Cocoyam (Xanthosoma sagittifolium) Starches from some locations in Mollucas}

\section{Cynthia G. C. Lopulalan',3, Djagal W. Marseno², Yustinus Marsono², Yudi Pranoto \\ ${ }^{1}$ Jurusan Teknologi Hasil Pertanian, Fakultas Pertanian, Universitas Pattimura Jl. Mr. Putuhena, Kampus Poka 97233, Ambon, Maluku Indonesia \\ ${ }^{2}$ Jurusan Teknologi Pangan dan Hasil Pertanian, Fakultas Teknologi Pertanian, Universitas Gadjah Mada, Jl. \\ Flora No. 1 Bulaksumur, Yogyakarta 55281, Indonesia \\ ${ }^{3}$ Mahasiswa Pendidikan Doktor, Fakultas Teknologi Pertanian, Universitas Gadjah Mada, Jl. Flora No. 1, Bulaksumur, Yogyakarta, 55281 Indonesia}

*Penulis Korespondensi: Djagal W. Marseno, e-mail: djagal@ugm.ac.id

Tanggal submisi: 27 Juli 2020; Tanggal penerimaan: 5 April 2021

\begin{abstract}
This study aimed to characterize the physical and functional properties of cocoyam starch from several locations in Maluku. The use of starch in the processed food and non-food industries will be determined by its various characteristics depending on the starch source. It is expected from this research that data can be used to assess the potential of cocoyam starch in its use in the food and non-food industries. Cocoyam tubers from Maluku, i.e. Buru Island, Saparua Island, and Saumlaki Island were used as samples in this research.. The wet extraction method was used to produce cocoyam starch in this research. Physical properties such as tuber length and diameter, tuber skin color, yield were analyzed. Swelling power and solubility, water holding capacity (WHC), paste clarity, pH and color were among functional properties observed. The results showed that the length of cocoyam tubers from the three sample locations was in the range of $8.75-36 \mathrm{~cm}$ with a diameter of $8-22 \mathrm{~cm}$. The skin color of the tubers was found to be blackish-brown, and the color of the tubers is white with a starch yield of 12-16\%. Based on the statistical analysis results, starch's functional properties like swelling power, solubility, WHC, paste clarity, pH, and color for the three starches were not significantly different from one another. This shows that differences in growing locations within an archipelago did not affect cocoyam starch's functional properties.
\end{abstract}

Keywords: Cocoyam starch; functional property; location; physical property

(C) The Authors. Publisher Universitas Pattimura. Open access under CC-BY-SA license.

\section{ABSTRAK}

Tujuan dari penelitian adalah mengkarakterisasi sifat fisik dan fungsional pati keladi yang berasal dari beberapa lokasi di Maluku. Karakteristik yang berbeda berdasarkan sumber pati akan menentukan kesesuaian pemanfaatannya dalam industri pangan olahan maupun non pangan. Diharapkan dari penelitian ini adalah diperoleh data yang dapat digunakan untuk mengkaji potensi pati keladi dalam penggunaanya di industri pangan maupun non pangan. umbi keladi yang digunakan sebagai sampel dalam penelitian ini berasal dari dari lokasi di Maluku yaitu umbi keladi asal pulau Buru, pulau Saparua dan pulau Saumlaki. Metode ekstraksi yang di gunakan dalam penelitian ini untuk menghasilkan pati keladi adalah metode ekstraksi basah. Parameter yang dianalisis meliputi sifat fisik yaitu panjang dan diameter umbi, warna kulit umbi, rendemen; serta sifat fungsional yaitu swelling power dan sollubility, water holding capacity (WHC), kejernihan pasta, $\mathrm{pH}$, warna. Hasil yang diperoleh adalah panjang umbi keladi dari tiga lokasi sampel adalah 8,75-36 cm dengan diameter 8-22 cm. Warna kulit umbi coklat kehitaman dan warna umbi putih serta rendemen pati 12-16\%. Berdasarkan hasil analisis statistik, sifat fungsional pati yaitu swelling power, sollubilty, WHC, kejernihan pasta, $\mathrm{pH}$ dan warna untuk ketiga pati tidak berbeda nyata satu dengan lainnya. Hal ini menunjukkan bahwa perbedaan lokasi tumbuh dalam satu kepulauan tidak mempengaruhi karakteristik fungsional pati keladi yang diteliti.

Kata kunci: Pati keladi; lokasi; sifat fisik; sifat fungsional

(C) Penulis. Penerbit Universitas Pattimura. Akses terbuka dengan lisensi CC-BY-SA. 


\section{PENDAHULUAN}

Indonesia adalah satu negara dengan sumber kekayaan hayati terbesar kedua setelah Brazil. Salah satu kekayaan hayati yang tumbuh sumbur di negeri ini adalah umbi-umbian (Faridah et al., 2014). Berbagai jenis umbian tersebar di hampir seluruh pelosok Indonesia dengan berbagai macam keanekaragaman umbian dan nama daerah. Salah satu umbian yang cukup terkenal dan tumbuh subur adalah keladi (Xanthosoma sagittofolium) yang dalam bahasa Indonesia disebut kimpul atau talas belitung. Keladi sendiri merupakan nama daerah Maluku dan penyebaran pertumbuhan tanaman keladi tersebar dari sabang sampai Merauke. Pemanfaatan keladi secara luas oleh masyarakat hingga saat ini masih terbatas pada pengolahan tradisonal atau pengolahan pada industri usaha kecil dan menengah seperti usaha keripik keladi dan oleh masyarakat dibeberapa daerah tertentu memanfaatkan batang dan daun keladi sebagai sayuran. Kandungan utama dari umbi keladi adalah karbohidrat, dimana pati memiliki porsi terbesar sehingga peluang pengembangan umbi keladi sebagai sebagai bahan pangan sumber pati non besar cukup besar dan berpotensi. Menurut Ojinnka dan Nnorom (2015), pati keladi mudah dicerna karena butiran pati yang kecil, kandungan kalsium, fosfor, vitamin $\mathrm{A}$ dan vitamin B yang tinggi. Pengolahan umbi keladi menjadi pati dapat meningkatkan nilai tambah umbi keladi tersebut. Selanjutnya pati keladi dapat dimanfaatkan sebagai bahan baku dalam industri makanan olahan seperti mie, cookies, produk bakery dan lain-lain. Pati diperoleh dari hasil ekstraksi tanaman, dimana tanaman sumber pati diantaranya jagung, umbi-umbian, pisang, barley, beras, sagu, sorgum, biji-bijian dan serealia. Pati adalah karbohidrat polimer glukosa yang terdiri atas amilosa dan amilopektin (Jacobs dan Delcour, 1998).

Keladi tumbuh sangat subur di Maluku, Maluku merupakan salah satu propinsi di Indonesia yang terdiri dari ribuan pulau kecil maupun besar dengan luasan lautan lebih besar dari daratan sehingga satu pulau dengan pulau yang terpisahkan oleh lautan. Tiga pulau di Maluku yang dijadikan tempat pengambilan sampel dalam penelitian ini yaitu Pulau Saparua, Pulau Saumlaki dan Pulau Buru merupakan pulau-pulau yang secara geografis berbeda satu dengan yang lain dimana berbeda sosial budaya dan pola budidaya pertanian. Keterpisahan antar pulau merupakan salah satu alasan dari penelitian ini dimana masing-masing pulau memiliki karakteristitik sendiri-sendiri. Pada ketiga lokasi, keladi tumbuh subur dengan produksi yang masih tergolong rendah karena masih dikelola dalam perkebunan rakyat secara tradisonal yang disebut dusung (lokasi pertanian berdasarkan kepemilikan keluarga). Pemanfataan umbi keladi masih belum dilakukan secara optimal, masih sebatas digoreng, direbus, dijadikan keripik. Penelitian tentang karakteristik fisik dan fungsional pati keladi dapat menjadi data pendukung dalam pemanfaatan pati dalam berbagai produk. Hal ini diperlukan karena sifat fisik dan fungsional pati akan berbeda berdasarkan sumber pati dan informasi tersebut menentukan kesesuaian pemanfaatannya dalam industri pangan olahan maupun non pangan. Diharapkan dari penelitian ini adalah diperoleh data yang dapat digunakan untuk mengkaji potensi pati keladi dalam penggunaanya di industri pangan mapun non pangan.

\section{METODE PENELITIAN}

\section{Bahan}

Umbi keladi asal kepulauan Maluku diambil dari tiga lokasi pulau yang berbeda yaitu Pulau Buru (KB), Pulau Saparua (KP) dan Pulau Saumlaki (KS) masing-masing berjumlah $25 \mathrm{~kg}$ umbi mentah. Umbi yang diperoleh, dipersiapkan di laboratorium untuk selanjutnya di ekstraksi dan analisis.

\section{Prosedur Penelitian}

Ekstraksi pati keladi dilakukan dengan metode basah. Umbi keladi dibersihkan dari kulit, dicuci dengan air mengalir hingga bersih. Selanjutnya umbi keladi diiris tipis dengan ketebalan 2 mm. Irisan umbi keladi kemudian dicuci dengan air mengalir hingga air cucian menjadi bening, yang bertujuan untuk menghilangkan lendir yang dihasilkan dari umbi. Selanjutnya irisan umbi yang telah dicuci dihancurkan dengan perbandingan air dan irisan umbi keladi 1:1 dan hasilnya berupa bubur umbi keladi diperas dengan menggunakan kain saring. Hasil perasan selanjutnya diendapkan selama 6 jam. Tahap berikutnya adalah memisahan air dan endapan yang terbentuk (pati basah). Pati basah yang dihasilkan selanjutnya dikeringkan selama 6 jam, suhu $50^{\circ} \mathrm{C}$ menggunakan pengering kabinet. Pati kering selanjutnya di hancurkan dan diayak dengan ukuran 80 mesh kemudian dikemas plastik. 


\section{Prosedur Analisis}

\section{Swelling Power dan Solubility (Adebowale et al., 2005)}

Pati didispersikan dengan akuades $1 \%(\mathrm{~b} / \mathrm{v})$ dalam tabung reaksi yang telah diketahui beratnya (b1). Kemudian panaskan pada penangas air (Memmert WNB 14) suhu $95^{\circ} \mathrm{C}$ selama 30 menit, lalu didinginkan hingga suhu kamar. Selanjutnya disentrifugasi (EBA 20, Hettich) dengan kecepatan $5000 \mathrm{rpm}$ selama 15 menit, sehingga terpisah residu dan supernatan. Supernatan $(10 \mathrm{~mL})$ dikeringkan hingga berat konstan pada suhu $105^{\circ} \mathrm{C}$ menggunakan oven UN 55 (Memert, Jerman). Residu yang terdapat setelah dikeringkannya supernatan, menunjukkan jumlah pati yang terlarut dalam air (\%). Residu dan air yang tertahan setelah sentrifugasi kemudian ditimbang (b2).

Swelling power (berdasarkan berat kering) ditentukan sebagai berikut:

Swelling power $(\mathrm{g} / \mathrm{g})=\frac{\mathrm{b} 2-\mathrm{b} 1}{\text { berat pati }} \times 100 \%$

Sollubilty $=\frac{\text { berat kering supernatan }}{\text { berat pati }} \times 100 \%$

\section{Kejernihan Pasta Pati (Waliszewski et al., 2003).}

Suspensi pati dibuat dengan konsentrasi $4 \%$ (w/w) dan dipanaskan pada penangas air dengan suhu $90^{\circ} \mathrm{C}$ selama 30 menit sambil digojog. Suspensi didinginkan hingga suhu $\pm 30^{\circ} \mathrm{C}$, kemudian disimpan pada ruang pendingin pada laboratorium Rekayasa Pangan FTP UGM pada suhu $4^{\circ} \mathrm{C}$ selama 125 jam dan setiap 24 jam diukur $\% \mathrm{~T}$ pada $\lambda 650$ mengunakan spektrofotometer UV-Vis $10 \mathrm{~S}$ (Genesys, China) dengan akuades sebagai blanko.

Water Holding Capacity (Ganjyal et al., 2003; Shimelis et al., 2006)

Sampel ditimbang sebanyak 0,5 g (BSA) dan disuspensikan dalam $5 \mathrm{~mL}$ akuades. Suspensi dicampur menggunakan vorteks selama 30 detik, kemudian didiamkan selama 30 menit. Suspensi disentrifugasi pada kecepatan 3000 rpm selama 10 menit. Cairan supernatan dipisahkan, endapan yang terbentuk ditimbang (BSAk). Daya rehidrasi ditentukan dengan:

WHC $(\%)=($ BSAk - BSA $) \times 100 \%$ berat sampel (basis kering)

\section{pH (Apriyantono et al., 1989)}

Nilai $\mathrm{pH}$ diukur setelah diinkubasi selama 0 , 24, dan 48 jam dengan menggunakan $\mathrm{pH}$ meter ST3100-B (Ohaus). pH meter dikalibrasi menggu- nakan larutan buffer $\mathrm{pH} 4$ dan 7. Timbang $1 \mathrm{~g}$ sampel, tambahkan $20 \mathrm{~mL}$ akuades kemudian aduk dengan menggunakan stirer sampai basah sempurna, kemudian tambahkan $50 \mathrm{~mL}$ akuades, aduk hingga homogen. Biarkan sampel selama 1 jam pada suhu ruang, jangan disaring, biarkan mengendap. Ukur pH supernatan sampel.

\section{Rendemen (Muchtadi dan Sugiyono. 1992)}

Rendemen pati keladi dapat dihitung berdasarkan perbandingan pati keladi dengan berat bahan dasar kering mula-mula (sebelum diolah).

$\%$ Rendemen $=\frac{\text { berat tepung }}{\text { berat bahan dasar kering }} \times 100 \%$

\section{Warna (Metode Hunter)}

Analisis warna menggunakan metode $L a b$ Hunter dengan alat Chromameter CR-300/310 (Minolta, Jepang). Sampel di masukan dalam cup plastik bulat, kemudian di ratakan permukaan, selanjutnya alat sensor di letakan pada permukaan cup, tombol power di tekan dan hasil uji yang terbaca di catat. Metode ini didasarkan pada tiga parameter, yaitu nilai $L^{*}$ yang menunjukkan tingkat kecerahan sampel. Skala nilai $L^{*}$ mulai dari 0 untuk sampel paling gelap hingga 100 untuk sampel paling cerah. Nilai $a^{*}$ menunjukkan warna kromatik campuran merah dan hijau. Nilai $a^{*}$ positif artinya warna sampel cenderung berwarna merah. Nilai $a^{*}$ negatif artinya sampel cenderung berwarna hijau. Nilai $b^{*}$ menunjukkan warna kromatik campuran kuning dan biru. Nilai $b^{*}$ positif artinya warna sampel cenderung berwarna kuning. Nilai $b^{*}$ negatif maka sampel cenderung berwarna biru.

\section{Analisis Data}

Data yang diperoleh dianalisis secara statistik dengan menggunakan analisis ragam pada tingkat kepercayaan 95\%. Jika perlakuan berpengaruh nyata atau sangat nyata maka analisis uji beda rataan dilanjutkan dengan uji Duncan's pada taraf $\alpha=0,05$.

\section{HASIL DAN PEMBAHASAN}

Berdasarkan Tabel 1 dapat dilihat bahwa kisaran panjang umbi keladi untuk ketiga lokasi pengambilan sampel adalah 8,75-36 cm, dimana umbi keladi KB memiliki ukuran umbi yang panjang. Sedangkan kisaran diameter umbi adalah $8-22 \mathrm{~cm}$. Warna kulit umbi coklat kehitaman (Tabel 1) dengan warna umbi putih. Ukuran, 
diameter serta warna kulit umbi sangat dipengeruhi oleh jenis tanah, unsur hara tanah serta waktu panen. Umbi keladi yang dipanen pada kondisi matang fisioligis (10 bulan) akan menghasilkan ukuran umbi yang maksimal dengan warna umbi yang coklat kehitaman serta kandungan lendir yang ada pada umbi menjadi lebih sedikit.

\section{Swelling Power dan Sollubilty}

Swelling power merupakan peningkatan volume dan berat maksimum yang terjadi pada pati di dalam air pada kisaran suhu $50-90^{\circ} \mathrm{C}$. Swelling power yang tinggi berarti semakin tinggi pula kemampuan pati mengembang di dalam air. Semakin tinggi kadar amilosa maka nilai pengembangan volume akan semakin tinggi (Murilo et al., 2008). Hasil analisis statistik menunjukkan nilai swelling power dari 3 sampel yang dianalisis menunjukkan hasil yang tidak berbeda nyata. Dari hasil ini bisa dikatakan bahwa perbedaan tempat tumbuh yang berada pada satu kepulauan tidak memberikan pengaruh terhadap nilai swelling power sampel. Jika hasil ini dibandingkan dengan hasil penelitian tentang pati keladi alami dari negara lain maka nilai swelling power pati keladi alami pada penelitian ini lebih tinggi dari swelling power pati keladi alami asal Nigeria 7,96 g/g (Arawande and Ashogbon, 2019), 8,45 g/g dan 10,09 g/g (Falade and Okafor, 2013), namun lebih rendah dari pati keladi alami beberapa aksesi asal Malawi dengan kisaran nilai swelling power pada suhu $90^{\circ} \mathrm{C}$ adalah 25-35 g/g (Mweta et al., 2010). Perbedaan nilai swelling power bergantung pada ukuran partikel pati, varietas dan lokasi tumbuh. Semakin besar ukuran granula pati maka nilai swelling power akan meningkat (Kaur et al., 2002).

Solubility atau kelarutan pati terjadi karena adanya ikatan non-kovalen antara molekul molekul pati. Bila pati dimasukan ke dalam air dingin, granula pati akan menyerap air dan membengkak. Meningkatnya kelarutan akan diikuti oleh peningkatan viskositas pati. Nilai kelarutan dari hasil penelitian ini tidak berbeda nyata antar ketiganya. Nilai kelarutan ketiga pati hasil penelitian masih lebih rendah dari nilai kelarutan pati keladi asal Nigeria yaitu 5,18 dan 8,19 (Falade dan Okafor, 2013) dan 14,03 (Arawande dan Ashogbon, 2019).

Tabel 1. Karakteristik fisik umbi keladi

\begin{tabular}{|c|c|c|c|c|c|c|}
\hline Sampel & Umbi Keladi & $\begin{array}{c}\text { Panjang } \\
\text { Umbi } \\
(\mathrm{cm})\end{array}$ & $\begin{array}{c}\text { Diameter } \\
\text { Umbi } \\
(\mathrm{cm})\end{array}$ & $\begin{array}{c}\text { Warna } \\
\text { Kulit } \\
\text { Umbi }\end{array}$ & $\begin{array}{l}\text { Warna } \\
\text { Umbi }\end{array}$ & $\begin{array}{c}\text { Rendemen } \\
\text { Pati }\end{array}$ \\
\hline KB & & $16-36$ & $8,75-11,5$ & Coklat & Putih & $16 \%$ \\
\hline $\mathrm{KP}$ & & $8,75-11,5$ & $8-11$ & Coklat & Putih & $15,6 \%$ \\
\hline $\mathrm{KS}$ & & $11,7-22$ & $11,7-22$ & Coklat & Putih & $12 \%$ \\
\hline
\end{tabular}

Keterangan: KB = Keladi Buru, KP = Keladi Porto, KS = Keladi Saumlaki 
Tabel 2. Hasil analisis parameter fungsional pati keladi dari beberapa lokasi di Maluku

\begin{tabular}{|c|c|c|c|c|}
\hline Sampel & $\begin{array}{c}\text { Swelling power } \\
(\mathrm{g} / \mathrm{g})\end{array}$ & Kelarutan (\%) & WHC (\%) & $\mathrm{pH}$ \\
\hline KB & 14,60 & 1,85 & 10,65 & 6,84 \\
\hline KP & 12,97 & 1,82 & 10,47 & 6,02 \\
\hline KS & 13,42 & 2,03 & 10,57 & 6,05 \\
\hline
\end{tabular}

Keterangan: KB = Keladi Buru, KP = Keladi Porto, KS = Keladi Saumlaki, WHC $=$ water holding capacity

\section{WHC}

WHC atau daya serap air merupakan kemampuan bahan pangan dalam menyerap dan menahan air didalam molekul bahan tersebut. Granula pati dapat menyerap air dan membengkak tetapi tidak dapat kembali seperti semula (Fennema, 1985). Kulp (1975) menyatakan bahwa air yang terserap dalam molekul menyebabkan granula mengembang. Nilai WHC dari hasil penelitian ini menunjukkan nilai yang tidak berbeda nyata antar ketiga pati yang diteliti. Nilai WHC sampel berkisar antara 10,47-10,65, nilai ini lebih rendah dari nilai WHC pati keladi alami asal Nigeria 21,0-23,5 (Falade dan Okafor, 2013) Dan hasil kedua jenis keladi ini juga lebih rendah dari nilai WHC Yam asal nigeria dari penelitian yang sama oleh Falade dan Okafor (2013) yaitu 27,0$36,0 \%$. Hasil ini menunjukkan bahwa perbedaan jenis varietas atau aksesi, lokasi tumbuh berpengaruh terhadap nilai WHC. Proses gelatinisasi akan merusak ikatan hidrogen intramolekuler. Ikatan hidrogen mempunyai peranan untuk mempertahankan struktur integritas granula. Terdapatnya gugus hidroksil yang bebas akan menyerap air, sehingga terjadi pembengkakan granula pati. Dengan demikian semakin banyak jumlah gugus hidroksil dari molekul pati maka kemampuan menyerap air semakin tinggi. Oleh karena itu absorbsi air sangat berpengaruh terhadap viskositas.

\section{Kejernihan Pasta}

Kejernihan pasta ketiga pati alami hasil penelitian mengalami penurunan selama penyimpanan $120 \mathrm{jam}$, dengan penurunan kejernihan hingga $<6 \% T$. Kejernihan pasta pati tertinggi hari ke-0 pada pati keladi alami KS, diikuti pati KP dan KB. Setelah dilakukan penyimpanan selama 120 jam pada suhu $4^{\circ} \mathrm{C}$ kejernihan pasta mengalami penurunan (Gambar 1). Hal ini sejalan dengan hasil penelitian sebelumnya yaitu pati sagu alami mengalami penurunan kejernihan pasta selama penyimpanan (Polnaya et al., 2018; Polnaya dan Puturuhu, 2010; Polnaya et al., 2009). Karam et al. (2005) juga mengemukakan bahwa setelah penyimpanan 72 jam sampel menjadi lebih keruh. Kejernihan pasta diukur untuk mengevaluasi tendensi retrogradasi. Jika pasta pati disimpan pada suhu rendah, maka proses retrogradasi cenderung berlangsung lebih cepat. Pasta pati yang dipanaskan sampai melampaui suhu gelatinisasi akan menyebabkan terurainya amilosa dari bagian pati ke bagian air. Pati alami memiliki suhu gelatinisasi yang paling tinggi. Apabila pati ini dipanaskan hingga melampaui suhu gelatinisasi pati maka amilosa akan terurai. Bila suhu pasta pati kemudian diturunkan hingga $25^{\circ} \mathrm{C}$, amilosa terurai cenderung saling bergabung/restrukturisasi dengan amilosa yang lain (retrogradasi). Kejernihan pasta pati dipengaruhi oleh penetrasi dan penyerapan air yang menyebabkan pengembangan granula yang kemudian meningkatan transmitan cahaya (Mboungeng et al., 2008) dan \% transmitansi pati mengalami penurunan dengan meningkatnya waktu penyimpanan (Lawal, 2004). Semakin meningkatnya pengembangan dan kelarutan granula pati dan yang menghalangi terjadinya gelatinasi menjadi faktor yang dapat meningkatkan kejernihan pasta pati. Pati yang memiliki nilai kejernihan pasta tinggi menghasilkan pasta pati dengan warna yang bening atau transparan, sehingga jika digunakan sebagai bahan baku akan menghasilkan produk dengan warna yang jernih atau transparan dan sebaliknya bila granula pati mengembang sedikit maka pasta yang dihasilkan keruh (Muzaifa et al., 2014).

\section{pH}

$\mathrm{pH}$ pati keladi alami hasil penelitian ini berkisar antara 6,05-6,85. Nilai $\mathrm{pH}$ ini lebih rendah dibandingkan dengan hasil penelitian pati keladi asal Nigeria yaitu 7,19 . Pengukuran nilai $\mathrm{pH}$ pati sangat penting karena berhubungan dengan aplikasi pada industri, pengukuran derajat asam dan alkali terutama pada media cair (Arawande dan Ashogbon, 2019).

\section{Rendemen}

Rendemen merupakan perbandingan dari berat bahan setelah proses dan berat bahan 
sebelum proses (berat bahan mentah). Keladi yang digunakan dalam penelitian ini adalah aksesi keladi yang berasal dari tiga lokasi yang berbeda di Maluku. Umumnya keladi dipanen pada umur panen delapan bulan setelah tanam. Pada usia panen tersebut dapat menghasilkan rendeman pati yang tinggi karena secara fisiologis keladi telah matang. Hal ini terjadi karena pada umur demikian menjadi usia optimal penyimpanan cadangan makanan, pada usia selanjutnya mulai terjadi degradasi pati menjadi serat dan pertumbuhan jaringan meristem pembentuk tunas baru (Damat et al., 2007). Kisaran nilai rendemen sampel dalam penelitian ini adalah $12-16 \%$, kisaran hasil ini lebih tinggi bandingkan pati garut yang dihasilkan oleh (Damat et al., 2016) dan Maulani et al., (2012) yaitu 13\%.

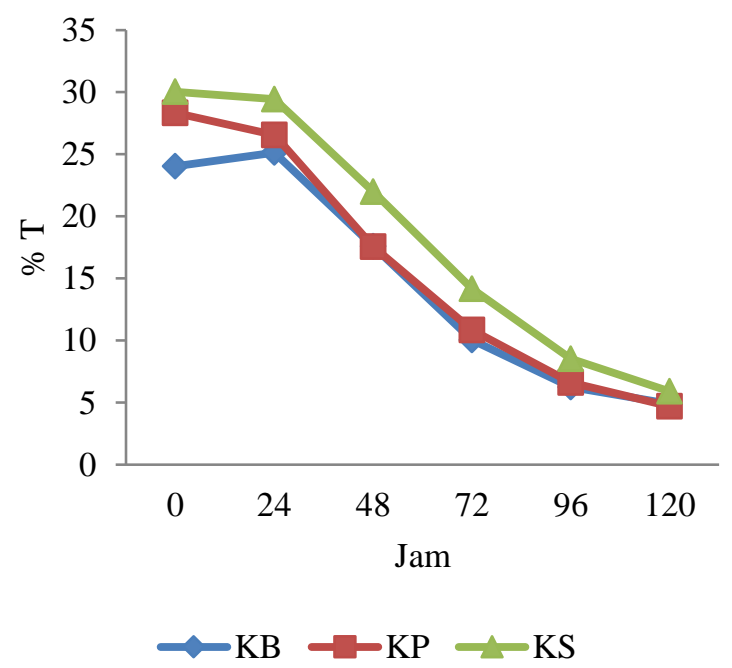

Gambar 1. Kejernihan pasta pati keladi dari beberapa lokasi di Maluku, selama 120 jam penyimpanan. $\mathrm{KB}=$ Keladi Buru, $\mathrm{KP}=$ Keladi Porto, $\mathrm{KS}=$ Keladi Saumlaki

Tabel 3. Hasil pengukuran warna pati keladi alami dari beberapa lokai di Maluku

\begin{tabular}{lccc}
\hline Parameter & $\mathrm{KB}$ & $\mathrm{KP}$ & $\mathrm{KS}$ \\
\hline$L^{*}$ & $91,28^{\mathrm{a}}$ & $91,34^{\mathrm{b}}$ & $91,35^{\mathrm{b}}$ \\
$a^{*}$ & $5,85^{\mathrm{b}}$ & $5,71^{\mathrm{a}}$ & $5,72^{\mathrm{a}}$ \\
$b^{*}$ & $-2,24^{\mathrm{b}}$ & $-2,38^{\mathrm{a}}$ & $-2,67^{\mathrm{a}}$ \\
\hline
\end{tabular}

Keterangan: Superscript yang berbeda dalam satu kolom menunjukkan terdapat perbedaan berdasarkan uji Tukey $(\mathrm{p}<0,05)$.

\section{Warna Pati}

Hasil pengukuran warna pati alami dengan chromameter disajikan pada Tabel 3. Nilai $L^{*}$ atau tingkat kecerahan KB berbeda nyata dengan nilai $L^{*} \mathrm{KP}$ dan KS. Kisaran nilai $L^{*}$ ketiga pati alami yang diteliti adalah 91,28-91,35 yang menunjukkan warna sangat putih.

\section{KESIMPULAN}

Lokasi tumbuh yang berbeda karena daerah kepulauaan tidak memberikan pengaruh yang nyata terhadap sifat fisik dan fungsional pati keladi yang diteliti. Hasil analisa karakteristik fisik dan fungsional pati keladi dapat menjadi bahan acuan untuk melakukan modifikasi pati sesuai kebutuhan pengolahan pangan dan industri.

\section{DAFTAR PUSTAKA}

Adebowale, K.O., B.I. Olu-Owolabi, E.K. Olawumi, and O.S. Lawal. 2005. Functional properties of native, physically and chemically modified breadfruit (Artocarpus artilis) starch. Industrial Crops and Products 21: 343-351. DOI: 10.1016/ j.indcrop.2004.05.002

Apriyantono A., D. Fardiaz, N.L. Puspitasari, S. Yasni, dan S. Budijanto. 1989. Petunjuk Laboratorium Analisis Pangan. Departemen Pendidikan dan Kebudayaan, Pusat Antar Universitas Pangan dan Gizi, Institut Pertanian Bogor, Bogor

Arawande, J.O. and A.O. Ashogbon. 2019. Isolation and characterization of starch obtained from cocoyam cultivated at Akungba Akoko. Ondo State. Nigeria 6.

Damat, Y. dan Kurniawati. 2016. Karakteristik fisiko-kimia pati garut (Marantha arundinaceae) termodifikasi secara fisik melalui proses gelatinisasi-retrogradasi berulang. Seminar Nasional Hasil Penelitian, 2016-UNMUH.

Falade, K.O. and C.A. Okafor. 2013. Physicochemical properties of five cocoyam (Colocasia esculenta and Xanthosoma sagittifolium) starches. Food Hydrocolloids 30: 173-181. DOI: 10.1016/j.foodhyd.2012. 05.006

Faridah, D.N., D. Fardiaz, N. Andarwulan, dan T.C. Sunarti. 2014. Karaketristik sifat fisikokimia pati garut (Maranta arundinaceae). Agritech 34: 14-21.

Fennema OR, 1985. Food Chemistry. Marcel Dekker Inc. New York. Basel

Ganjyal, G.M., M.A. Hanna, and D.D. Jones. 2003. Modelling selected properties of 
extruded waxy maize cross-linked starches with neural networks. Journal of Food Science 68: 1384-1388. DOI: 10.1111/ j.1365-2621.2003.tb09654.

Jacobs, H. and J.A. Delcour. 1998. Hydrothermal Modifications of granular starch, with retention of the granular structure: A review. Journal of Agricultural and Food Chemistry 46: 2895-2905. DOI: 10.1021/jf980169k

Karam, L.B., M.V.E. Grossmanna, R.S.S.F. Silvaa, C. Ferrerob, and N.E. Zaritzky. 2005. Gel textural characteristics of corn, cassava and yam starch blends: A mixture surface response methodology approach. Starch/Stärke 57: 62-70. DOI: 10.1002/star. 200400328

Kaur, L., N. Singh, and N.S. Sodhi. 2002. Some properties of potatoes and their starches II. Morphological, thermal and rheological properties of starches. Food Chemistry 79: 183-192. DOI: 10.1016/S0308-8146(02) 00130-9

Kulp K, 1975. Carbohydrate. Didalam G Reed (Ed). Enzymes in Food Processing. Academic Press. New York.

Lawal, O. 2004. Composition, physicochemical properties and retrogradation characteristics of native, oxidised, acetylated and acidthinned new cocoyam (Xanthosoma sagittifolium) starch. Food Chemistry 87: 205-218. DOI: 10.1016/j.foodchem.2003. 11.013

Maulani, R.R., R. Budiasih, dan N. Immaningsih. 2012. Karakterisasi fisik dan kimia rimpang dan pati garut (Marantha arundinaceae L.) pada berbagai umur panen. Prosiding Seminar Nasional: Kedaulatan Pangan dan Energi Fakultas Pertanian Universitas Trunojoyo Madura.

Mboungeng, P.D., D. Tenin, J. Scher, and C. Tchíégang. 2008. Physicochemical and functional properties of some cultivars of irish potato and cassava starch. Journal of Food Technology 6: 139-146.

Muchtadi, T.R. dan Sugiyono. 1992. Petunjuk Laboratorium Ilmu Pengetahuan Bahan Pangan. PAU Pangan dan Gizi. IPB. Bogor

Murilo-Chávez, C.E., Y-J. Wangb, and L.A. BelloPérez. $2008 . \quad$ Morphological, physicochemical and structural characteristics of oxidized barley and corn starches. Starch/Stärke 60: 634-645. DOI: 10.1002/star.200800016

Muzaifa Murna, M.I. Sulaiman, dan Liyuza. 2014. Evaluasi Sifat fisik pati ganyong (Canna edulis Kerr.) sebagai bahan baku pembuatan kwietaiw pada tingkat subtitusi yang berbeda. Sagu 13: 35-40.

Mweta, D.E., M.T. Labuschagne, S. Bonnet, J. Swarts, and J.D.K. Saka. 2010. Isolation and physicochemical characterisation of starch from cocoyam (Colocasia esculenta) grown in Malawi. Journal Science of Food and Agriculture 90: 1886-1896. DOI: $10.1002 /$ jsfa. 4029

Ojinnaka, M.C. and C.C. Nnorom. 2015. Quality evaluation of wheat-cocoyam-soybean cookies. Nigerian Journal of Agriculture, Food and Enviroment 11: 123-129.

Polnaya, F.J., A.A. Huwae, dan G. Tetelepta. 2018. Karakteristik sifat fisiko-kimia dan fungsional pati sagu ihur (Metroxylon sylvestre) dimodifikasi dengan hidrolisis asam. Agritech 38: 7-15. DOI: $0.22146 /$ agritech.16611

Polnaya, F.J. dan B.R.I. Puturuhu. 2010. Preparasi dan karakterisasi pati asetil. Buletin BIAM 6: 10-13.

Polnaya, F.J., J. Talahatu, Haryadi, dan D.W. Marseno, 2009. Karakterisasi tiga jenis pati sagu (Metroxylon sp.) hidroksipropil. Agritech 29: 87-95.

Shimelis, E.A., M. Meaza, and S.K. Rakshit. 2006. Physico-chemical properties, pasting behavior and functional characteristics of flours and starches from improved bean (Phaseolus vulgaris L.) varieties grown in East Africa. Agricultural Engineering International: the CIGR Ejournal. Manuscript FP 05 015. Vol. VIII. February, 2006.

Waliszewski, K.N., M.A. Aparicio, L.A.Bello, J.A. Monroy. 2003. Changes of banana starch by chemical and physical modification. Carbohydrate Polymers 52: 237-242. DOI: 10.1016/S0144-8617(02)00270-9 